\title{
PReS-FINAL-2336: Induction of MDSCS in Muckle-Wells syndrome
}

\author{
N Rieber* , A Brand, D Neri, T Hall, I Schäfer, S Hansmann, J Kümmerle-Deschner, D Hartl \\ From 20th Pediatric Rheumatology European Society (PReS) Congress \\ Ljubljana, Slovenia. 25-29 September 2013
}

\section{Introduction}

Muckle-Wells syndrome (MWS) is caused by mutations in the NLRP3-gene encoding cryopyrin, leading to overproduction of IL-1 $\beta$ and other NLRP3 inflammasome products. Myeloid-derived suppressor cells (MDSCs) represent a novel innate immune cell subset, are generated in tumor, infective, and proinflammatory microenvironments and are capable of suppressing $\mathrm{T}$ cell responses. Consequently, MDSCs are considered a key intermediary in balancing innate and adaptive immune responses, particularly under chronic disease conditions.

\section{Objectives}

We hypothesized that NLRP3 inflammasome-dependent factors induce the generation of MDSCs in MWS.

\section{Methods}

We studied granulocytic MDSC numbers in 25 MWS patients under anti-IL-1 therapy with canakinumab and 20 healthy controls. After Ficoll density gradient sedimentation, granulocytic MDSCs were characterized as $\mathrm{CD} 33^{\text {high }} \mathrm{CD} 66 \mathrm{~b}^{\text {high }} \mathrm{IL}-4 \mathrm{R} \mathrm{a}^{\text {inter }} \mathrm{HLA}-\mathrm{DR}{ }^{\text {low }}$ neutrophilic cells in the PBMC fraction, according to previously established human MDSC analysis methods. The functionality of MACS-isolated MDSCs was assessed using polyclonal $\mathrm{T}$ cell proliferation and cytokine/chemokine secretion tests. Physician's global assessment of disease activity, CRP, ESR, and T helper cell subsets were determined at the same time points and correlated with MDSC levels. Serum samples of 22 MWS patients and 5 healthy controls were examined by multiplex technique for possible MDSC inducing factors.

\footnotetext{
Children's Hospital, Autoinflammation Reference Center, University of
} Tübingen, Tübingen, Germany

(c) 2013 Rieber et al.; licensee BioMed Central Ltd. This is an Open Access article distributed under the terms of the Creative Commons Biomed Central Attribution License (http://creativecommons.org/licenses/by/2.0), which permits unrestricted use, distribution, and reproduction in any medium, provided the original work is properly cited. The Creative Commons Public Domain Dedication waiver (http:// creativecommons.org/publicdomain/zero/1.0/) applies to the data made available in this article, unless otherwise stated.

\section{Results}

MWS patients under anti-IL-1 therapy displayed significantly elevated MDSC numbers (mean $1.65 \pm 0.33 \%$; range $0.16-5.17 \%$ ) compared to healthy controls (mean $0.45 \pm 0.05 \%$; range $0.12-1.04 \% ; p=0.0025)$, although clinical MWS-disease activity was generally low at time of examination. MDSCs were functionally competent, as they suppressed polyclonal $\mathrm{T}$ cell proliferation, Th1, Th2, and Th17 responses. MDSCs correlated directly with Treg/Th17 and Treg/Th1 ratios indicating an influence on $\mathrm{T}$ helper cell subsets. Multiplex assays revealed the established MDSC-inducing growth factors GM-CSF and VEGF elevated in MWS sera even under anti-IL-1 therapy with canakinumab.

\section{Conclusion}

MWS patients under anti-IL-1 therapy display significantly elevated numbers of granulocytic MDSCs. Increased MDSCs in MWS might represent a novel autologous antiinflammatory mechanism in autoinflammatory conditions and may serve as a future therapeutic target.

\section{Disclosure of interest}

N. Rieber Grant/Research Support from: NR, JKD, and DH obtained research grants from Novartis GmbH, Consultant for: NR and JKD took part in advisory boards for Novartis GmbH, A. Brand: None Declared, D. Neri: None Declared, T. Hall: None Declared, I. Schäfer: None Declared, S. Hansmann: None Declared, J. KümmerleDeschner: None Declared, D. Hartl: None Declared.

Published: 5 December 2013 